\title{
INDIA'S MISSING WORKING WOMEN: HOW COVID-19 PUSHED WOMEN OUT OF FORMAL LABOUR MARKETS
}

\author{
Mitali Nikore ${ }^{1}$, Manvika Gupta ${ }^{2}$, Poorva Prabhu ${ }^{3}$ and Vidhi Narang ${ }^{4}$ \\ ${ }^{1}$ Founder, Nikore Associates, 401, Iris Tower, Salcon the Verandas, Golf Course Road, Sector 54, \\ Gurgaon \\ ${ }^{2,3,4}$ Research Advisor, Nikore Associates \\ DOI: 10.46609/IJSSER.2021.v06i04.015 URL: https://doi.org/10.46609/IJSSER.2021.v06i04.015
}

\begin{abstract}
India's women were disproportionately impacted by COVID-19 induced lockdowns and economic disruptions. Recent high frequency data demonstrates that that women suffered massive job and income losses. In December 2020, nine months into the lockdown, there were still 11.5 millionfewer persons in the labour force vs. December 2019, 4 million men and 7.5 million women. The overall size of the labour force shrunk by $2.6 \%$ between December 2019 to December 2020, yet the size of the female labour force shrunk by $14 \%$, vs. $1 \%$ for men. Women faced stricter mobility restrictions, limiting their access to workplaces. Across income strata, women's unpaid domestic responsibilities increased, with some estimates showing a 30\% increase in carework, leaving them little time for seeking renumerated employment. Gender digital divides worsened, leaving women without access to digital business and online education, increasingly important in a post-COVID-19 economy. Most importantly, women faced the scourge of the shadow pandemic of domestic violence, rendering them insecure and unable to work. Despite being one of the world's fastest growing emerging economies, only a quarter of Indian women were in the labour force even pre-COVID-19. Analysis of time series data over the last five decades (1970-2018), shows that women's labour forceand workforce participation rates have secularly declined to their lowest levels since Independence. Given this disparate impact of COVID-19, in the absence of targeted policy interventions designed to support retention and promote women's workforce participation, women are likely to continue being excluded from India's spectacular growth story.
\end{abstract}

Keywords: Women, labour force, wage gaps, India, post-COVID-19 recovery

\section{Introduction}

The workforce is not a 'gender neutral' sphere where only one's qualifications, skills, and performance determine entry into or progress in a profession. Starting from the very decision to 


\section{International Journal of Social Science and Economic Research}

ISSN: $2455-8834$

Volume:06, Issue:04 "April 2021"

gainan education, to entering the labour force, to the kind of work they can take on, to the hours they canspend at work, and even the location of their workplace, Indian women face restrictions owing to deeply entrenched patriarchal norms. The burden of domestic work and unpaid care further inhibits women's ability to acquire skills for better jobs, leading to a vicious cycle, such that women continue being kept out of the labour force. Consequently, women's work has remained largely informal, invisible, and labour-intensive. (Sudharshan and Bhattacharya, 2008). In this context, the imposition of the COVID-19-induced national lockdown in March 2020, followed by intermittent localised lockdowns, and the looming threat of the COVID-19 pandemic, and the onset of the second wave up to the writing of this paper in April 2021, put women's already poor levels of job security at even greater risk.

This paper aims to shed light on the impact of COVID-19 on women's work by studying five trends that affected them disproportionately: massive job and income losses, mobility restrictions, unpaid domestic work, gender-based digital divides, and the shadow pandemic of domestic violence. We hope to contribute to the research on women's economic empowerment, documenting the conditions that have affected women's labour force and workforce participation through data analysis, secondary research and literature reviews.

\section{Methodology}

This paper follows a mixed methods approach. Secondary data analysis helped in capturing historical trends in labour market outcomes. An analysis of time series data (at the all-India level) over the last five decades (1970-2018) was conducted to examine the trends in labour market outcomes. This data was sourced from Periodic Labour Force Surveys conducted by the National Sample Survey Organisation, published by the Ministry of Statistics, Programming and Implementation, Government of India. Monthly data on key labour market indicators, published by the Centre for Monitoring Indian Economy's (CMIE) Economic Outlook Database, was used to study the impact of COVID-19 on women's economic participation. This was followed by a thorough review of literature, complemented by consultations with academics and field practitioners to help in contextualising the findings, appreciating the underlying causes of observed trends and developing forward-looking recommendations.

\section{Historical trends in women's labour market outcomes}

\subsection{Female Labour Force and Workforce Participation}

The female labour force participation rate (FLFPR) is the proportion of women in the population who are working or are looking for work. Rising from about $24 \%$ in 1955-56, the FLFPR (for all ages) peaked at 33\% in 1972-73. It then showed a decline till 1999-00, when it touched $26 \%$. It increased mildly to $29 \%$ in $2004-05$ only to reduce to a dismal $17.5 \%$ in 2017 - 
International Journal of Social Science and Economic Research

ISSN: 2455-8834

Volume:06, Issue:04 "April 2021"

18 - its lowest ever in the history of Independent India, improving slightly to $18.6 \%$ in $2018-19$. The FLFPR for 15 years and above declined steadily from $47 \%$ in $1987-88$ to $24 \%$ in $2018-19$. The difference between the proportion of men and women in the labour force has remained at about 40 percentage points over the last five decades.

The rural FLFPR (15 years and above) nearly halved, falling from 53.7\% in $1987-88$ to $26.4 \%$ in 2018-19, with a marginal uptick to $26.4 \%$ in 2018-19. On the hand, the urban FLFPR fell from $26.1 \%$ in $1987-88$ to $19.4 \%$ in $2009-10$ and has remained flat at about $20.5 \%$ since $2011-12$. Thus, the exodus of rural women from the labour force was as a key driver of falling FLFPR, especially since 2004 .

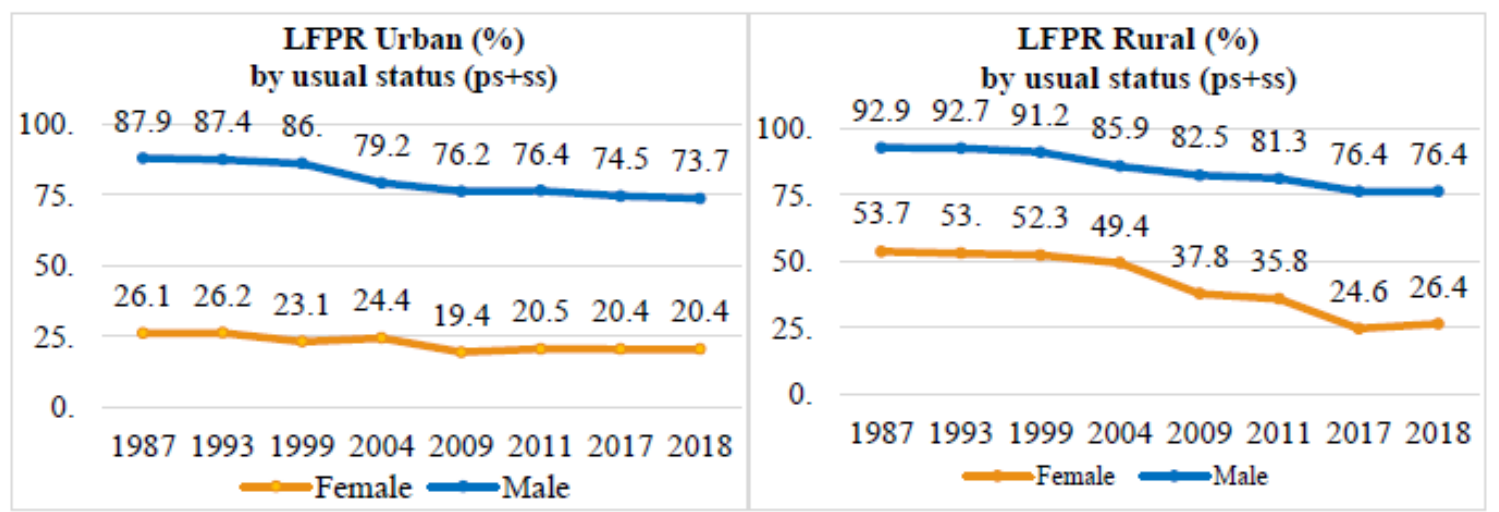

Fig. 1: Labour participation rate for men and women (15 years and above) in rural and urban areas (1987-2018). (Source: Data from National Sample Survey Organisation)

Throughout the four decades starting from the 1980s, the proportion of working women(15 years and above) witnessed a secular decline. Between 1987-88 to 2018-19, the rural female workforce participation rate (FWPR) fell from $52.8 \%$ to $25.5 \%$ and the urban FWPR fell from $25.1 \%$ to $18.4 \%$. On the other hand, rural male WPR declined from $91.1 \%$ to $72.2 \%$, and urban male WPR declined from $84.5 \%$ to $68.6 \%$. Unemployment rates for women remained consistently higher than men between 1972-73 to 2018-19. URs for both men and women showed sudden spikes over the 2011-12 to 2018-19 period. Notably, the UR for urban women increased from 5.2\% to $10.8 \%$ (the highest since 1977-78) and saw a mild decrease to $9.9 \%$ in 2018-19, while for rural women it increased from $1.7 \%$ to $3.5 \%$.

Notably, there was an increase in the proportion of employed women working as salaried or regular workers, in urban areas. In rural areas, $2.8 \%$ of working women were regular workers in $1983-84$, vs. $10.3 \%$ of working men. These proportions changed to $11 \%$ and $14.2 \%$ in $2018-19$. This trend was even more pronounced in urban areas, where the proportion of women in salaried 
International Journal of Social Science and Economic Research

ISSN: 2455-8834

Volume:06, Issue:04 "April 2021"

work almost doubled from $25.8 \%$ to $54.7 \%$ between $1983-84$ and 2018 -19, vs. a just a 4 percentage point increase for men, from $43.7 \%$ in $1983-84$ to $47.2 \%$ in $2018-19$.

About $35 \%$ of rural female workers were engaged as casual labour in 1983-84; this reduced only slightly to about 29.3\% in 2018-19 (Any person who was casually engaged in others' farm/nonfarm enterprises - both household and non-household - and, in return, received wages as per the terms of the daily/periodic work contract, is considered as casual labour). Rural males engaged in casual labour fell marginally from $29 \%$ in $1983-84$ to $28 \%$ in $2018-19$. On the other hand, with increasing participation in salaried employment, women's engagement in casual labour in urban areasmore than halved from $28 \%$ in $1983-84$ to $10 \%$ in $2018-19$. For urban males however, there was no such decline, as their participation in casual labour remained stagnant, $15.4 \%$ in $1983-84$ to $14.2 \%$ in 2018-19. Thus, casual labour has continued to be the norm for rural women over the last five decades.

\subsection{Wage Differentials}

Wages for women have remained fundamentally low and the gender wage gap has remained sticky over the last three decades, i.e. between 1993-2018. Average female wages for casual workin rural areas have stood at $\sim 66 \%$ of the male wage. For casual work in urban settings, this increased in 2018 to only $63 \%$ of the male wage. Regular rural workers saw the gender wage ratio improve (59\% to 64\%). Gender wage gaps were lowest for urban salaried workers; the gender wage ratio remained at $\sim 79 \%$.

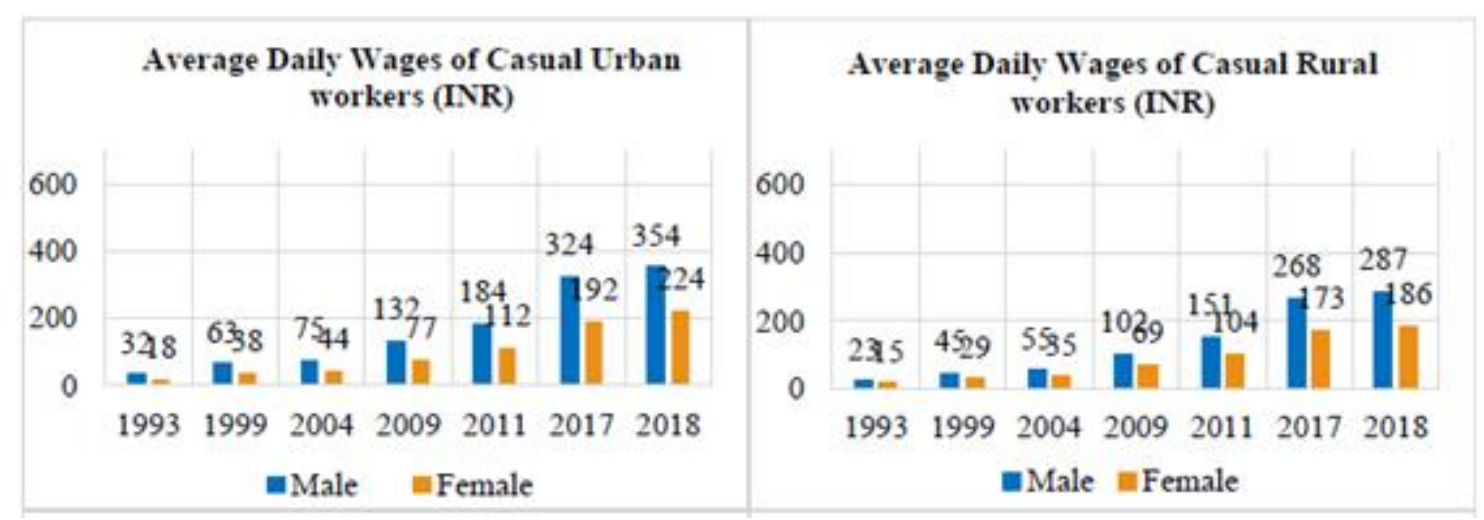




\section{International Journal of Social Science and Economic Research}

ISSN: $2455-8834$

Volume:06, Issue:04 "April 2021"

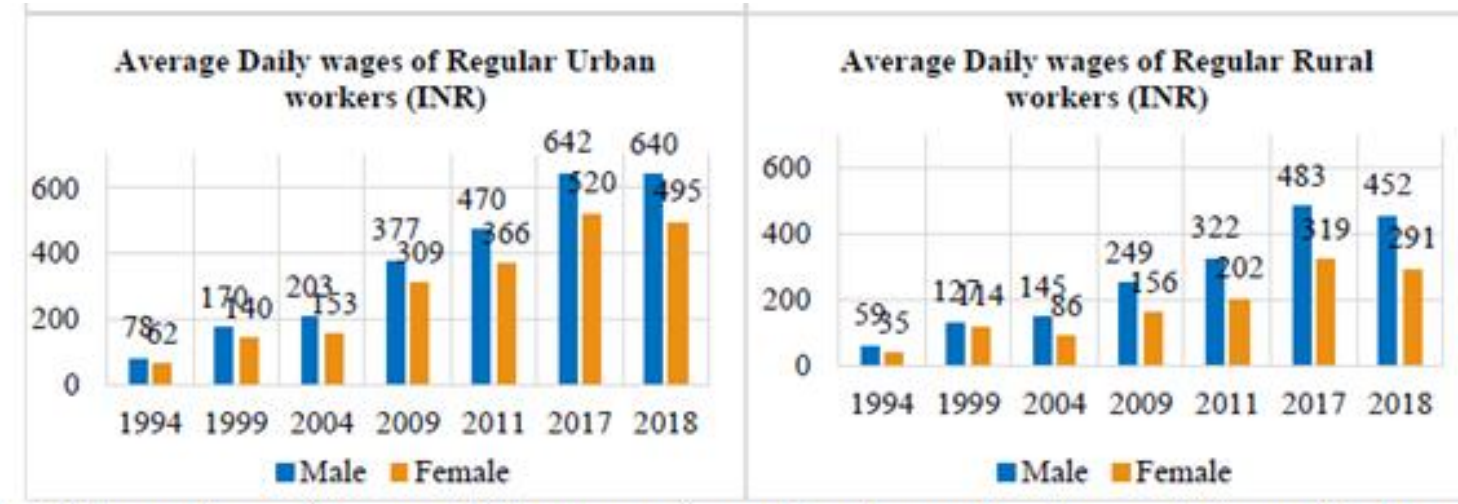

Fig. 2. Comparison of average daily wages of casual/regular workers by gender in rural/urban areas (1993-2018) (Source: Data from National Sample Survey Organisation)

A survey of the literature provides several explanations for these trends. Men tend to migrate to urban areas as rural wages are about 1/3rd the urban wage, leaving women in low-paying rural jobs (ILO, 2018). Sticky stereotypes of "women's work" being labour intensive, coupled with low levels of skilling, leads to women performing unskilled/helper roles in the organised manufacturing sector, resulting in lower wages (Galbraith et al., 2004; Dutta, 2005; Das, 2007). Career breaks and the ensuing loss of experience due to childbirth lead to "motherhood penalties" to the extent of 3\%-10\% per child globally (Bhalla and Kaur, 2011; Agüero et al., 2020). In India, almost $69 \%$ of women in the formal workforce expect a pay cut when restarting their careers post motherhood (Rajesh et.al., 2019), and mothers are likely to receive fewer call-backs to their applications (Bedi et al.). Ultimately, the perception and positioning of women as supplementary wage earners can explain the existence of gender pay gap even when a man and women are at similar education and experience levels, workingin the same industry. (Duflo, 2012; Das, 2012; Varkkey et al., 2017).

\section{Impact of COVID-19 on women's work}

Over the last seven decades, women's labour force and workforce participation has reduced and consistently remained below that of men. There has been an exodus of women from the labour force, particularly in rural areas. A high proportion of working women are in casual employment, especially in rural areas, vis-à-vis men. With the imposition of a nation-wide lockdown in March 2020, gender gaps in labour market outcomes widened. CMIE data reveals the deepest impact on labour market outcomes was felt in the months of April/May 2020, with some improvement in June/July, and a second dip in August/September owing to rising COVID19 caseloads. While there was a slight improvement in October, this was followed by deeper losses in November and December. We explore the five trends driving these gender gaps, their 
International Journal of Social Science and Economic Research

ISSN: 2455-8834

Volume:06, Issue:04 "April 2021"

likely role in post-COVID-19 recovery, and present finding from stakeholder consultations for the same.

\subsection{Massive Job and Income Losses}

A review of high frequency CMIE data reveals that not only were initial labour market impacts stronger for women, but the recovery of women's employment, particularly for those in urban areas, was slower as well. We explore the trends in labour force participation, workforce participation and unemployment below.

\subsubsection{Trends in labour force participation}

The immediate impact of the lockdown on labour force participation was disproportionately borne by women. The size of the labour force contracted from 433.8 million (383.4 million men, 50.4million women) in March 2020 to 369.0 million (332.0 million men, 37.0 million women) in April 2020. Between March-April 2020, 13.4 million women, (26.6\%), moved out of the labour force vs.51.4 million men (13.4\%).
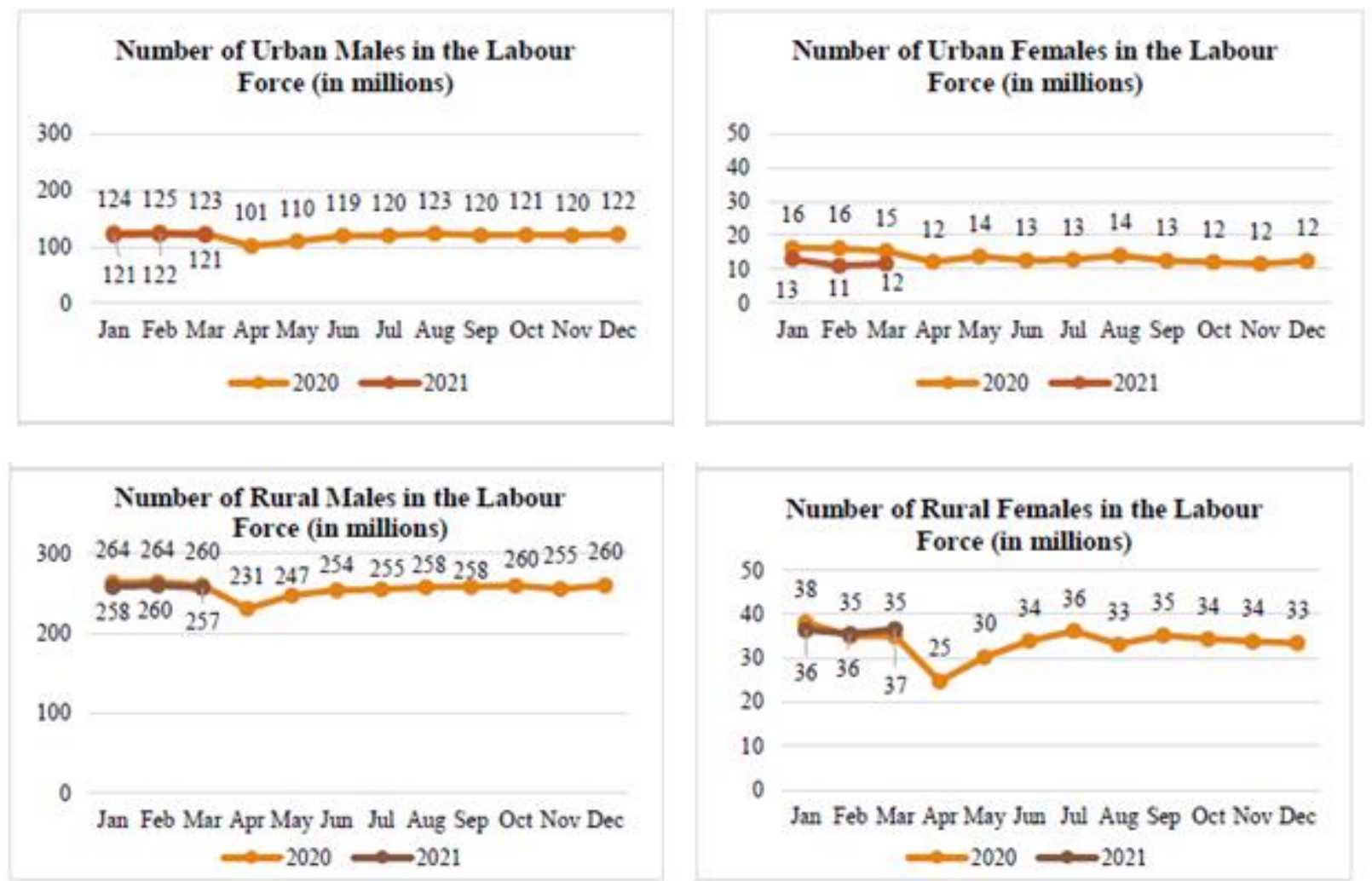

Fig. 3: Urban/rural men and women in the labour force (January-December 2020, January-March 2021) (CMIE). 


\section{International Journal of Social Science and Economic Research}

ISSN: 2455-8834

Volume:06, Issue:04 "April 2021"

In December 2020, nine months into the lockdown, there were still 11.5 million fewer persons in the labour force vs. December 2019, 4 million men and 7.5 million women. The overall size of thelabour force shrunk by $2.6 \%$ between December 2019 to December 2020, the size of the female labour force shrunk by $14 \%$, vs. $1 \%$ for men. Of these 7.5 million women displaced from the labour force, 4.7 million were rural women, vs. 2.8 million urban women. Urban women suffered the deepest losses, with labour force contracting by $18.3 \%$, vs. $3 \%$ for urban men. The rural labour force contracted by $12.3 \%$ for women, vs. $0.1 \%$ for men.
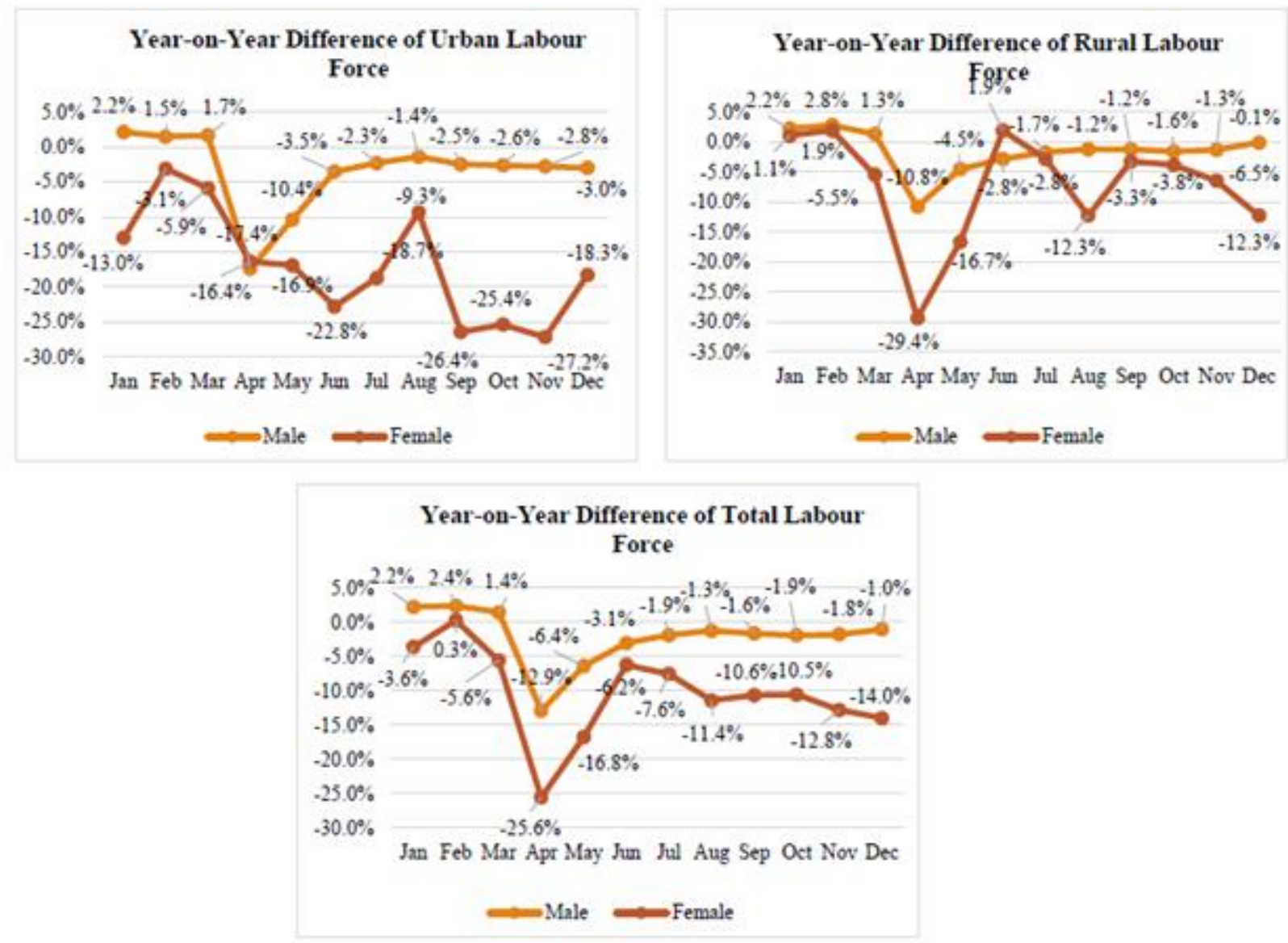

Fig. 4: Year-on-Year Difference of Labour Force (January-December 2020 vs. 2019) (CMIE).

In March 2021, one year into the initial lockdown, there were still 8 million fewer persons in the labour force vs. March 2020, with the overall size of the labour force shrinking by $1.8 \%$. A positive trend that has been observed over the period is the recovery in labour force participation of rural women, increasing by $4.6 \%$ from 35 million in March 2020 to 36.6 million in March 2021, vs. contracting by $1.3 \%$ for rural men. However, due to the onset of the second wave in March 2021, it remains to be seen whether this trend will continue. Urban women continue to suffer the 
International Journal of Social Science and Economic Research

ISSN: 2455-8834

Volume:06, Issue:04 "April 2021"

deepest losses, with labour force contracting by $24 \%$ (vs. $1.9 \%$ for urban men) with 3.7 million urban womenmoving out of the labour force over March 2020 to March 2021.

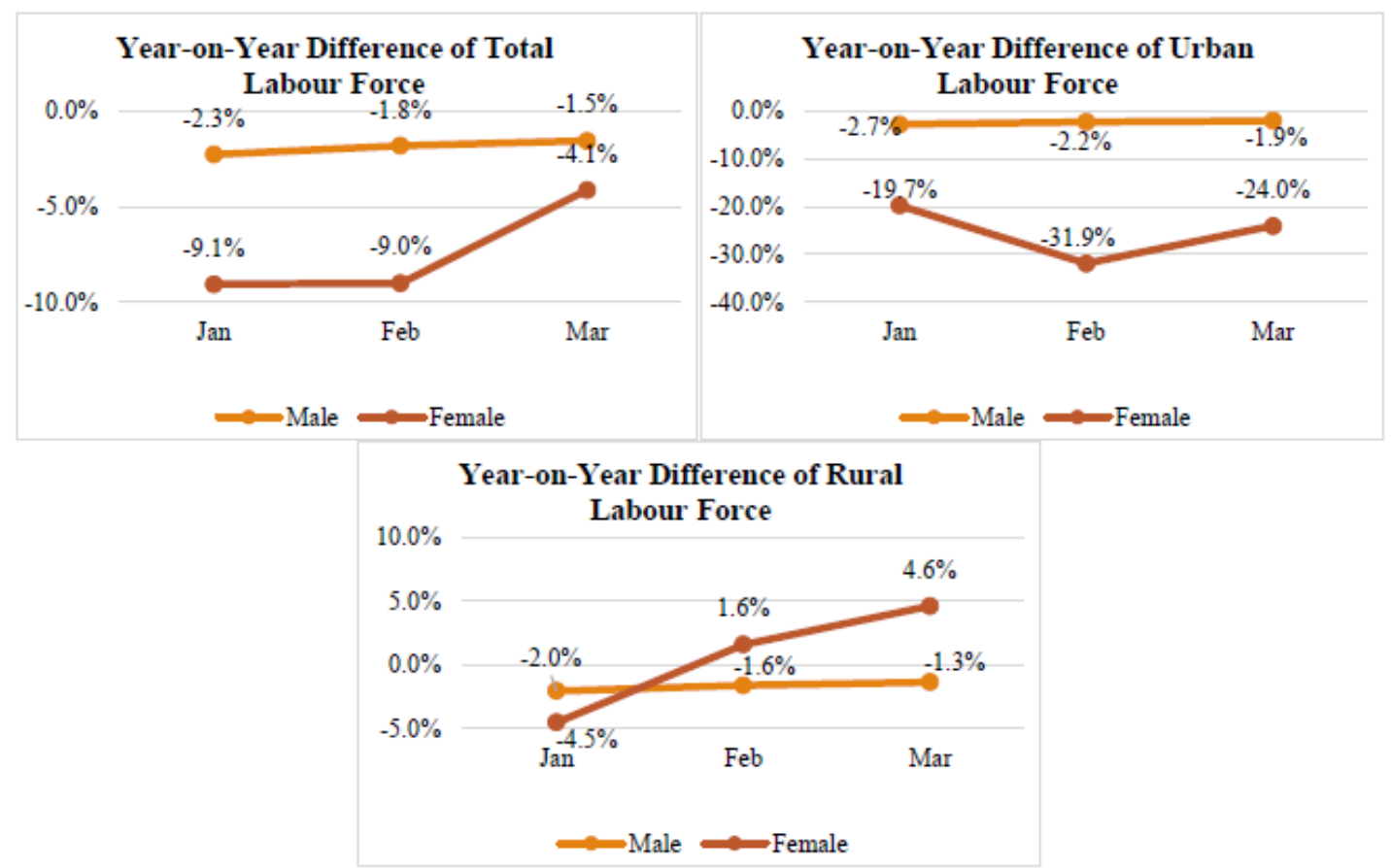

Fig. 5: Year-on-Year Difference of Labour Force (January-March 2021 vs. 2020) (CMIE).

\subsubsection{Trends in workforce participation}

113.6 million workers lost jobs between March-April 2020, of which 15.4 million were women. While the absolute fall in male employment was far greater, the proportionate fall for women was higher, as $37.1 \%$ of women lost their jobs, versus $27.7 \%$ men. As trade and mobility restrictions easedemployment recovered beyond March 2020 levels in March 2021, 393.5 million (November) vs. 398 million (March), before reducing back to 388.8 million in March 2021. However, the onset on the second wave in March 2021 is likely to hamper this recovery. 
International Journal of Social Science and Economic Research

ISSN: 2455-8834

Volume:06, Issue:04 "April 2021"
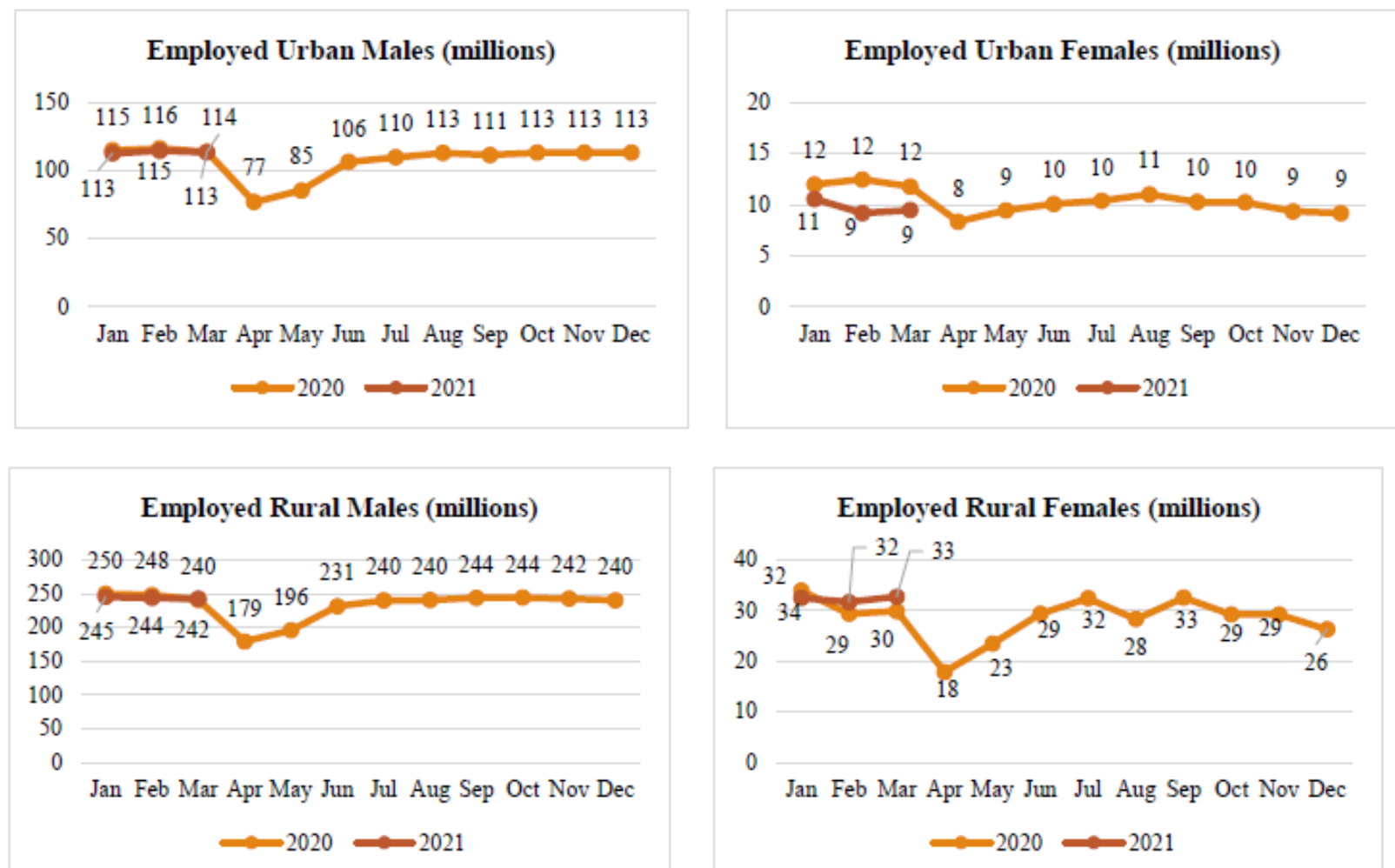

Fig. 6: Employed rural/urban men and women during the pandemic (January-December 2020 and January-March 2021) (CMIE).

Urban female employment fell from 11.8 million in March 2020 to 8.3 million in April 2020, i.e. by $29.2 \%$, vs. $32.4 \%$ for men, recovering to 9.2 million in December 2020, at an average recovery rate of (-)2.75\% between March-December 2020. Male employment, despite the higher initial shock, showed a higher average recovery rate of (-)0.05\%, almost bouncing back to prelockdown levels by August. Mr. Narayan Sen, the Founder of Adarsh Siksha Samiti which is a non-profit organization based in Rajasthan noted that sources of income and earnings decreased for women who belong to urban areas or are dependent on travelling to urban areas to earn their living owing to stricter lockdown conditions. 
International Journal of Social Science and Economic Research

ISSN: 2455-8834

Volume:06, Issue:04 "April 2021"

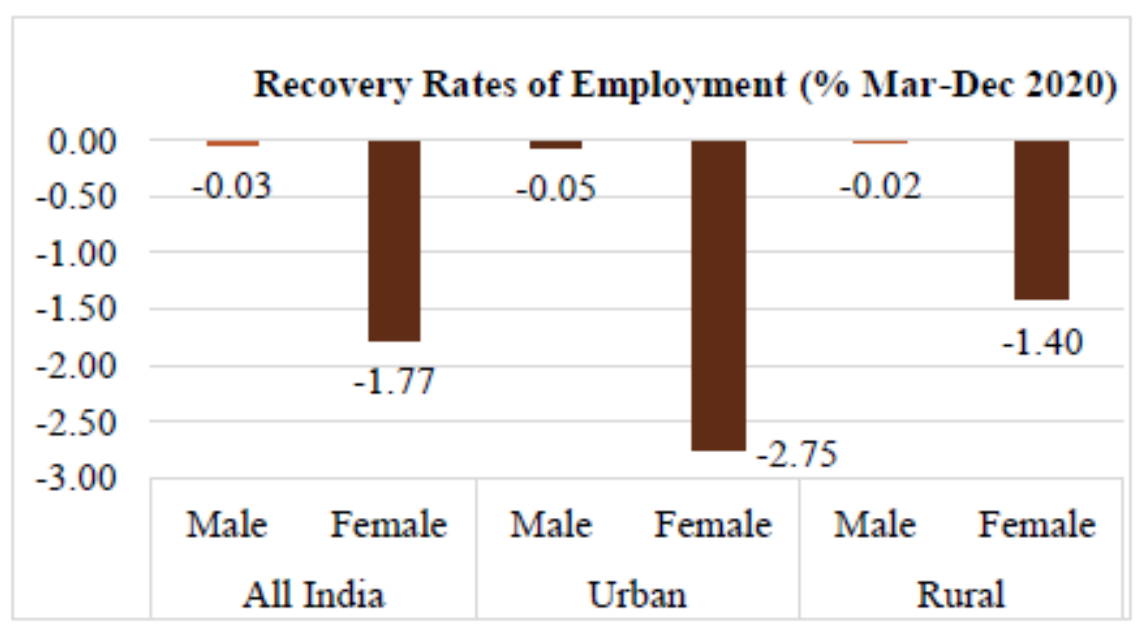

Fig. 7: Recovery rates of employment (March-December 2020) (CMIE).

Note: Recovery rate is calculated as the compounded average change in number of persons employed between March 2020 to December 2020.

Employed rural women experienced a steeper dip, from 29.8 million in March 2020 to 17.8 million in April 2020, i.e. by $40.2 \%$ vs. $25.5 \%$ for men. While recovery was rapid initially, with employment nearing pre-lockdown levels in June, a dip occurred in August followed by a temporaryuptick in September. There was a consequent fall in November and December resulting in an averagerecovery rate of (-) $1.40 \%$ between March to December. Rural men were the fastest to recover, at (-)0.02\%, with their absolute employment bouncing from back to March 2020 levels, 240.5 million (March) vs. 240.1 million (December). This was corroborated by consultations with women's groups, who pointed towards men being preferred for re-employment as the economy opens, especially in informal and unorganised sector, and in micro, small and medium enterprises (MSMEs).

Until March 2021 recovery rates continued improve for employment in both urban as well as rural areas. The highest improvement has been experienced in rural female employment, increasing from 41.6 million in 2020 to 42.2 million in March 2021 at an average recovery rate of $0.77 \%$ over the period. Total female employment increased to 42.2 million in March 2021 from 41.6 in March 2020 at an average recovery rate of $0.11 \%$, vs an average recovery rate of $0.04 \%$ for men (355.9 million in March 2021 from 354.2 in March 2020). While the recovery in female employment looks promising from this data, the trajectory of this recovery remains to be ambiguous at the onset of the second wave in India. 
International Journal of Social Science and Economic Research

ISSN: 2455-8834

Volume:06, Issue:04 "April 2021"

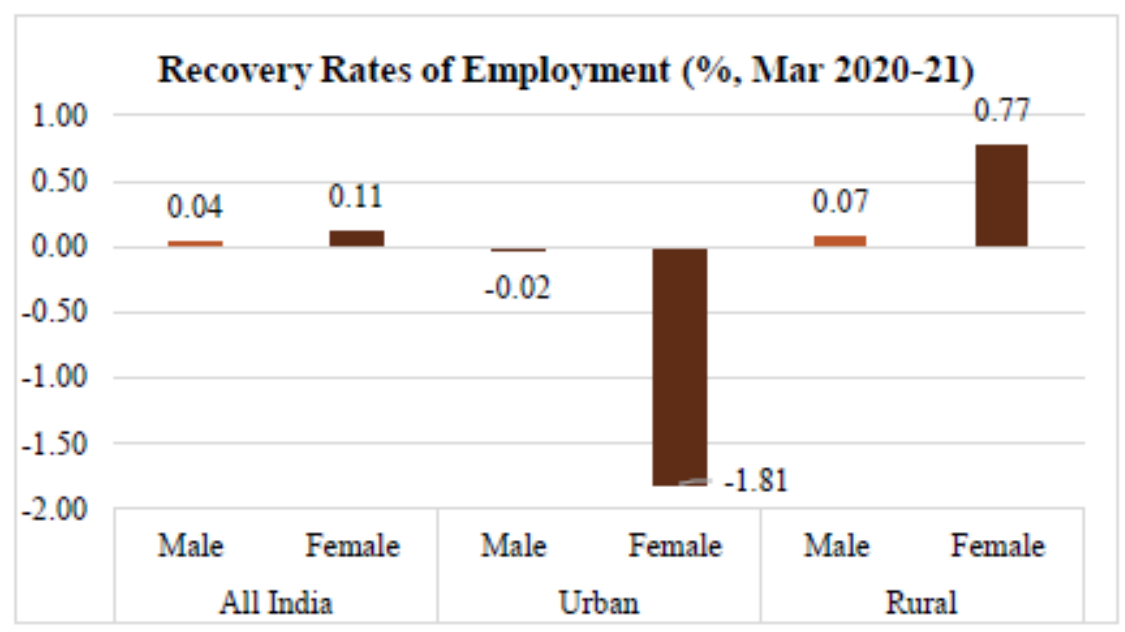

Fig. 8: Recovery rates of employment (March 2020-March 2021) (CMIE).

Note: Recovery rate is calculated as the compounded average change in number of persons employed between March 2020 to March 2021.

\subsubsection{Prevalence of unemployment}

Female URs were higher than male URs throughout the period of study, and the lockdown hasonly amplified female unemployment. Both male and female URs were highest during the first two months of lockdown. In March 2021, female UR was 12.7\%, lower than 17.4\% in March 2021, and male UR was $5.7 \%$ vs. $7.6 \%$ in March. Yet, these low URs do not fully reveal the depth of unemployment. In March 2021, of the 29.3 million unemployed men, 21.6 million (73.7\%) were actively looking for employment. In comparison, only 6.2 million of the 14.5 million unemployed women $(42.3 \%)$ did the same, suggesting that falling URs are a sign of being discouraged by economic conditions, especially for women.
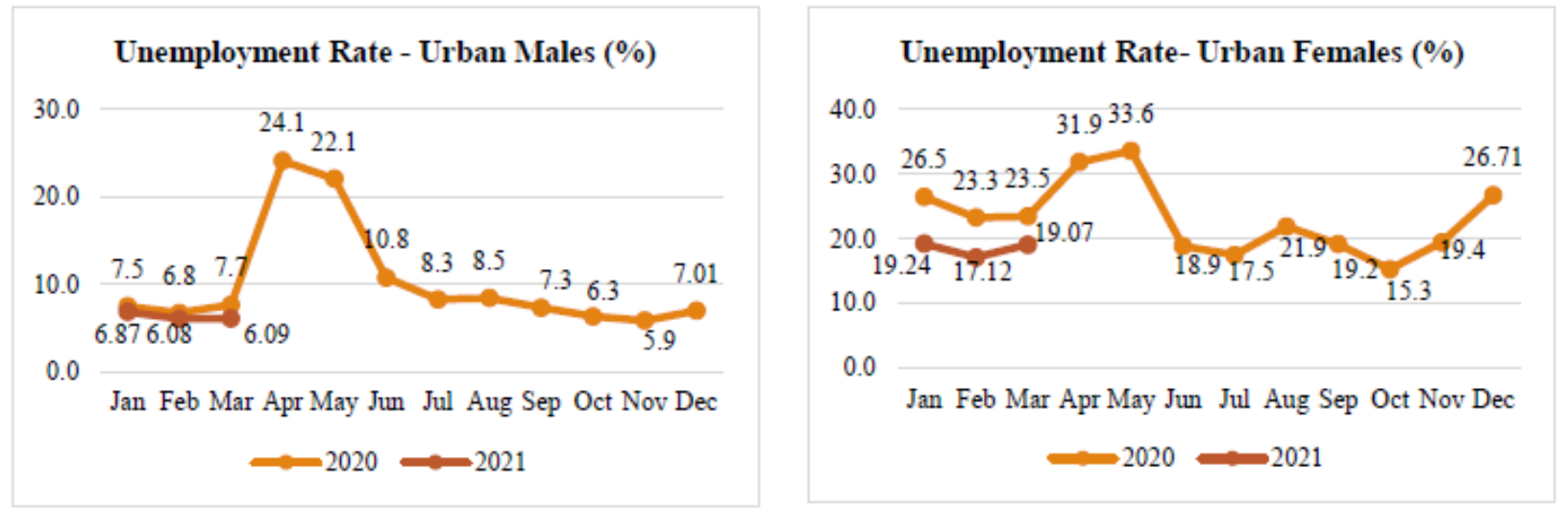


\section{International Journal of Social Science and Economic Research}

ISSN: $2455-8834$

Volume:06, Issue:04 "April 2021"
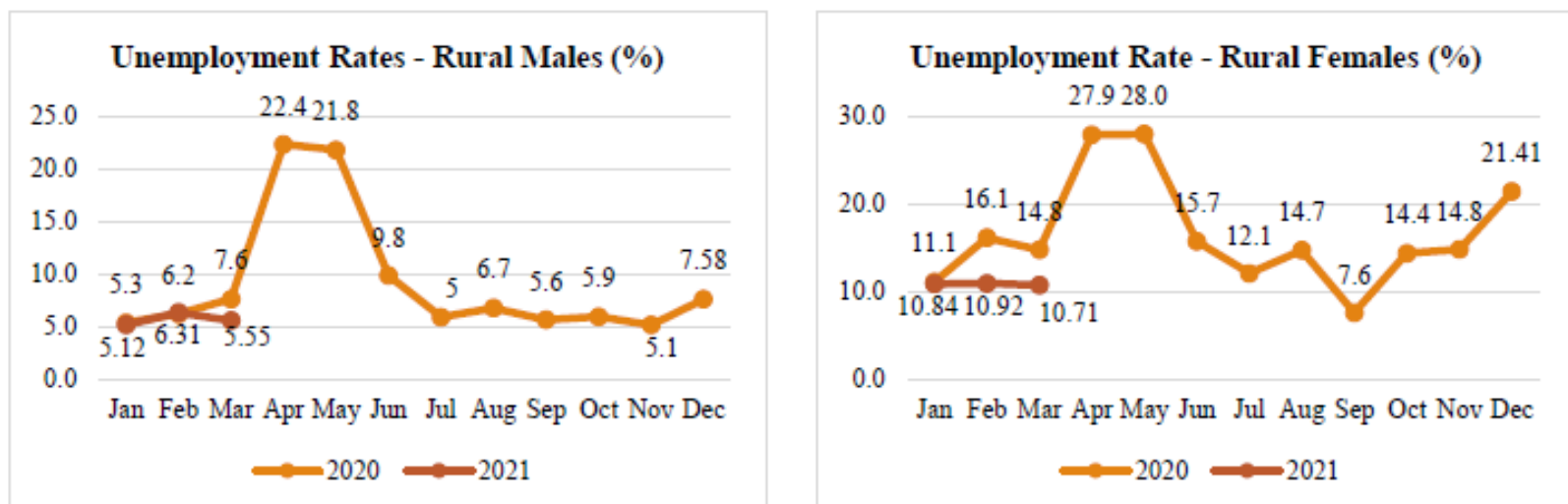

Fig. 9: Rural/urban URs by gender during the pandemic (January-December 2020, January-March 2021) (CMIE).

\subsubsection{Income losses of women-owned businesses}

Of the 61 million MSMEs in India, only 20\% are women-owned. Almost $90 \%$ are sole proprietorships, and nearly $48 \%$ are rural (vs. $88 \%, 34 \%$ for men). Women-owned enterprises remain concentrated in certain sectors, 35\% in personal services, $31 \%$ in wearing apparel and textiles and $15 \%$ in food and other services (IFC, 2018). These small businesses, which largely operate in consumer facing sectors (e.g. textiles, food-processing, handicrafts, etc.) witnessed a sharp demand shock with the onset of the nation-wide lockdown, and their revival has been slow. In a July 2020 survey, women-led enterprises reported a 72.5\% drop in revenue, with $88 \%$ utilising personal savings to meet working capital needs (IWWAGE, 2020). Weavers, artisans and home-based solopreneurs were left with unclaimed inventories owing to order cancellations (SEWA Bharat, 2020).

Stakeholder consultations illustrated several disruptions in supply chains. A waste recycling entrepreneur from Madhya Pradesh experienced increased raw material costs as newspaper circulation reduced during the pandemic. With lockdowns, access to physical marketplaces was restricted. Jute entrepreneurs in West Bengal stated they experienced a sharp decline in bulk supply orders for their products and being heavily dependent on sales from exhibitions and fairs, lost a considerable proportion of their annual income owing to their cancellation. Access to finance and shortage of working capital emerged as the most common constraint, cited by nearly every respondent. Women entrepreneurs from Telangana in the textile sector stated that while the government had provided some relief through moratorium on interest payments, it was only for a short period. They soon faced the prospect of restarting interest payments, had the burden of loan repayment, even though they had not been able to restart production, and demand was nowhere near pre-COVID-19 levels. Several other women from self-help-groups (SHGs) 


\section{International Journal of Social Science and Economic Research}

ISSN: $2455-8834$

Volume:06, Issue:04 "April 2021"

acknowledged that while loans were easier to avail as an SHG member, the savings amounts deposited with SHGs reduced over lockdown periods. With household incomes reducing, replenishing their deposits in the SHG was also challenging.

In an attempt to mitigate their losses, women entrepreneurs pivoted to alternative products like masks, sanitisers, personal protective equipment and cotton nightgowns. Some entrepreneurs also experimented with food delivery. Women-led SHGs manufactured 170 million masks, 530,000 PPE kits, 513,000 litres of sanitiser. They operated 123,000 community kitchens from MarchNovember 2020 (Ministry of Rural Development, 2020). However, they perceived the income generated from these channels were merely short-term solutions.

\subsection{Mobility Restrictions}

Even before COVID-19, only 54\% of women were allowed to go a nearby market alone, andonly $48 \%$ could visit places outside their village or community by themselves (National Family and Health Survey 2015-16). Women are less likely to own or control family/personal transport, and are heavily reliant on public transport services. In urban areas, even though they comprise $19 \%$ of "other workers", 84\% of their trips are made using public transport (Cropper, 2019; ITDP and Safetipin, 2018). Heightened mobility restrictions and disruption of public transport services lowered women'saccess to workplaces, hampering their ability to participate in the labour force and earn livelihoods, even as physical workplaces restarted operations.

Several stakeholders shared that they required strong reasons to leave the home, inhibiting their ability to work, run businesses, study or avail healthcare services and Government aid both during and after the lifting of official lockdowns. Consequently, women's financial independence and personal agency was eroded. Representatives from Azad Foundation (a community-based organisation), shared that patriarchal notions of women remaining within the home, performing unpaid care or domestic work, were more difficult to challenge owing to COVID-19 restrictions. Nearly $85 \%$ of the women training with Azad Foundation to become cab drivers reported that they faced restrictions on their mobility from their family, particularly the men in their households. Several stakeholders pointed that bank branches are at a long distance from habitations, and ATMs are not commonplace in rural areas. Mobility restrictions placed on women due to social norms were compounded by heavy policing during the lockdown, thus making it difficult to access government'scash transfers. Women entrepreneurs from Andhra Pradesh also stated that the lack of public transportation during lockdown and risk of COVID-19 exposure deterred them going to work, thus leading to job losses.

\subsection{Increased burden of domestic work}




\section{International Journal of Social Science and Economic Research}

ISSN: $2455-8834$

Volume:06, Issue:04 "April 2021"

On average, women spent 5 hours per day on unpaid household and caregiving work, vs. 30 minutes for men in 2019, i.e. nearly ten times as much as men. (NSSO Time Use Survey, 2019). Across income classes, women bore a greater burden of unpaid care work, be it childcare due to schoolclosures or elderly care owing to pressure on healthcare services during lockdowns, with some surveys reporting nearly 30\% increase in urban women's care work (Dalberg, 2020). In a recent survey of informal workers, $66 \%$ of women indicated increases in unpaid domestic work and $36 \%$ stated child/elderly care work increased during the lockdown's first two months (Chakraborty, 2020). Homemakers looking for employment declined between March and September 2020, from 6.4 millionto 2.5 million, recovering to 5.3 million in November (CMIE). Nearly $43 \%$ of urban female solopreneurs reported a loss of productivity due to increased domestic work during COVID-19 (Bain,2020).

Stakeholder consultations highlighted how unpaid work and lack of childcare facilitiesremained an obstacle to rejoining work for women. Apanalaya, a community organisation running Community Childcare Centers (CCC) for women in Mumbai's informal settlements shared they had 44 functional CCCs pre-COVID-19. As of September 2020, only 6 had reopened. The fear of COVID-19, coupled with fall in household incomes meant that families were either unwilling or unable to send their children to CCCs. This meant several women from the community could not re-join work, as they had no access to affordable childcare services. Even the women running CCCs lost their livelihood. Thus, women from this community were plunged into a vicious cycle and poverty trap owing to the sudden loss of incomes.

An SHG community mobiliser in Telangana noted that women earlier working in SHGs, nearby factories or local shops withdrew from work owing to household responsibilities. During the lockdown, as male family members were spending more time at home, there was a reduction in women's independence as they actively disallowed women from voicing opinions, or providing inputsinto household decisions.

Moreover, with school closures, it was not only married women, but adolescent girls whose time on domestic work increased. Stakeholders shared that a gender divide emerged with girls havingto take care of younger siblings, as parents had to leave homes to resume work post the lockdowns. Further, while boys were taking up manual labor or agricultural fieldwork, girls were made to stay home for household duties. This loss of precious years of education reduces girls' chances of completing higher education, skill training and eventually joining the workforce.

\subsection{Increasing gender-based digital divides}

In India, $63 \%$ of adult women own a mobile phone, but only $21 \%$ use mobile internet, vs. $79 \%$ and $42 \%$ adult men, respectively (GSMA, 2020). Women are systematically denied access to 


\section{International Journal of Social Science and Economic Research}

ISSN: $2455-8834$

Volume:06, Issue:04 "April 2021"

technology, with their use of mobile phones governed by male relatives (Harvard Kennedy School, 2018). With online learning and skilling, telemedicine, and work from home becoming the norm, andblended modes expected to continue even after COVID19, women are at risk of getting left behind, unable to acquire the skills required to participate in a digital economy.

SHG members from West Bengal reported a hesitancy and lack of confidence in shifting to online marketplaces. Lack of access to personal mobile phones, cost of data and limited knowledge of social media and digital marketing channels meant they were unwilling to invest in a transition to online selling. Women entrepreneurs from Maharashtra shared that even though women in their community were using smartphones for personal use, they were unable to make financial transactions online, and lacked digital financial literacy. An educator from Madhya Pradesh shared that girls were missing out on online classes due to lack of access to smartphones and mobile data. He shared his observations that in several households with both a male and female child, the male child is given the mobile phone for pursuing his online classes and not the girl.

On a more optimistic note, Mann Deshi Foundation, a community based financial services enterprise in Maharashtra offered low-interest loans to women for buying smartphones. Eventually, around $80 \%$ of the women in their community availed the scheme and purchased smartphones. MannDeshi then shifted their training programmes to virtual platforms. Around 15 trainers taught women how to make face masks and sell them via WhatsApp. Between March August 200, over 400 women produced more than 450,000 masks. Women entrepreneurs were provided with the necessary tools to shift and expand their businesses online, helping them sustain their incomes. Additionally, a virtual market place ("e-bazaar") was launched during Diwali (November 2020) with more than 3,000 listedproducts, and met with immense success. Several assigned "Digital Didis" were actively engaged in community education and helped the women navigate online platforms. Mann Deshi also partnered with companies like Google, IBM and WhatsApp to increase the women's digital literacy.

\subsection{The "shadow pandemic" of domestic violence}

India is a country where every third woman faces some form of domestic violence, and $52 \%$ of women and $42 \%$ of men believe it is justified for a husband to hit his wife (NFHS-4, 2015-16). the shadow pandemic of domestic violence only exacerbated women's challenges during COVID-19. Social isolation and mandatory confinement with potential abusers increases risk of domestic violence. Ravindran \& Shah (2020) showed evidence of a $131 \%$ increase in domestic violence complaints in May 2020 in red zone districts that saw the strictest lockdown measures relative to green zone districts with the least strict measures. Red zone districts also experienced a $184 \%$ increase in cybercrime complaints relative to green zone districts in May 
International Journal of Social Science and Economic Research

ISSN: 2455-8834

Volume:06, Issue:04 "April 2021"

2020. The National Commission of Women (NCW) received 13,410 complaints of crimes against women between March - September 2020, of which 4,350 were domestic violence. Complaints peaked in the March - May period, with 1/3rd of complaints being filed in these 3 months alone.

Efforts were made to ensure that existing Central government schemes such as One Stop Centres, Ujjawala Homes, and Emergency Response Support System remain operational throughout the lockdown. Notably, 33\% of violence complaints were made via the NCW's WhatsApp based helpline launched in April 2020, suggesting that a discreet method of reporting was much needed during the pandemic. State government initiatives, such as Uttar Pradesh Police's "Suppress corona, not your voice" campaign, Odisha Police's Phone-Up programme, Kerala State Commission for Women's tele-counseling facility, Maharashtra Government's Akshara Centres, Special Cell for Women and Children, and the \#LockdownOnDomesticViolence campaigns were important steps, signalling intolerance for domestic violence across governments.

The threat of domestic violence breaks a women's confidence, thereby making it difficult forher to hold a job. On the other hand, the lack of financial independence makes women even more susceptible to remaining in a violent relationship. Moreover, as historical evidence shows, only $14 \%$ of women who have ever experienced violence seek help making it clear that figures of reported violence are only the tip of the iceberg.

\section{Charting a gender sensitive socio-economic recovery}

An analysis of data over the last seven decades shows that women's work is largely informal, invisible and labour-intensive. Women's labour force and workforce participation has declined, and consistently remained below that of men. There has been exodus of women from the labour force, particularly in rural areas. There is a preponderance of women in traditional sectors with low labour productivity, such as agriculture, handicrafts, handlooms and textiles. Despite improvements in education, rising household incomes, liberalisation and increased linkages with global value systems, the exodus of India's women from the labour force continues. In this context, the COVID-19 pandemic has come as a shock, resulting in massive job losses for women, especially informal workers, and the slower recovery of women-led microbusinesses. It has also increased domestic work, deepened gender digital divides, exacerbated gender-based skill and educational gaps and placed millions of female health workers at risk.

India introduced a strong emergency response to COVID-19 lockdowns, offering free food grains, free gas cylinders, and direct cash support to low-income women. In the post-COVID-19 years, Central / State governments, the private sector and community-based organisations need to 
International Journal of Social Science and Economic Research

ISSN: 2455-8834

Volume:06, Issue:04 "April 2021"

come together to chart a gender-sensitive socio-economic recovery strategy for India. This includes acombination of short and long-term measures.

Drawing on the experience of measures introduced by developing countries post COVID-19, India should expand the immediate support offered to women in the short term, as follows:

1. Expanding cash transfers for vulnerable women, below poverty line. Post COVID19, Indonesia expanded its conditional cash transfer (CCT) program from 9.2 to 10 million households with mothers and children and increased the frequency of transfers from quarterly to monthly. The Government increased assistance for households with pregnant women by $25 \%$ for 3 months. Philippines, where a CCT program with $85 \%$ women beneficiaries has been operational since 2010, signed the Pantawid Pamilyang Pilipino Program (4P) Act into law in April 2019 to ensure its sustainability through adequate government support. Post COVID-19, women from 4.2 million 4P families were targeted for unconditional emergency cash transfers.

2. Incentivize retaining women informal workers in the labour force. In Thailand, women were overrepresented in highly affected sectors, such as manufacturing (48\%), accommodation and food services (63\%), health and social work (76\%), education (65\%), andhome-based domestic work (86\%). The Government is providing (i) $\$ 160$ per person per month for 3 months to 16 million people, at least $45 \%$ women, not covered by the social security system (SSS); (ii) \$32 monthly for 3 months to 14.6 million low income earners, of whom 8.3 million are women; (iii) SMEs employing 48\%-50\% women can avail tax deductionupon employee retention, as well as withholding tax deductions; and (iv) Women who lost their jobs can enroll for free online skills training and their children are provided with free milk.

3. Support for women owned businesses. Cambodia is targeting that at least $20 \%$ of SME borrowers under its low-interest Enterprise loan program should be women. Colombia announced a $\$ 4.8$ billion credit line for women entrepreneurs. Turkey is providing grants worth almost $\$ 19,000$ each for women-led co-operatives. Morocco has created a digital platform for marketing local products from women's co-operatives. Egypt has allocated $\$ 0.3$ billion to finance more than 200,000 women-led micro-projects over the next 5 years.

4. Increase compensation of ASHA \& Anganwadi workers. ASHA and Anganwadi workers are providing last mile contract tracing and COVID-19 survey activities. Globally, countries are enacting measures to ensure gender parity in compensation of male and female health workers, and providing financial support for childcare of female essential personnel. Increasing salaries of ASHA \& Anganwadi workers, in line with benefits announced for 


\section{International Journal of Social Science and Economic Research}

ISSN: $2455-8834$

Volume:06, Issue:04 "April 2021"

healthcare sector workers should be a priority.

In the long, three important steps need to be considered. First, the Central Government should work on boosting gender budgets (currently averaging 5\% of total expenditure between 200809 to 2019-20), to support national, State and district-level authorities in implementing programmes to improve women's lives and livelihoods. Second, all public and private stakeholders should collect gender-disaggregated data by default to aid targeted policymaking. Third, women's representation indisaster-response decision-making must increase at all levels to increase the likelihood of gender- sensitive policy design. India must keep women at the heart of economic recovery, and create opportunities to bring its "missing" women under the spotlight.

\section{Acknowledgements}

Research assistance from Ashruth Talwar, Chandni Ganesh and Shruti Jha is acknowledged.

\section{References}

[1] Arjun Bedi, Tanmoy Majilla and Matthias Rieger, "Gender Norms and the Motherhood Penalty: Experimental Evidence from India," IZA Institute of Labor Economics. 2018. Available at http://ftp.iza.org/dp11360.pdf.

[2] Asian Development Bank, "Proposed Countercyclical Support Facility Loan Kingdom of Cambodia: COVID-19 Active Response and Expenditure Support Program," 2020. Available at https://www.adb.org/sites/default/files/project-documents/54195/54195-001rrp-en.pdf

[3] Asian Development Bank, "Proposed Countercyclical Support Facility Loans, Kingdom of Thailand: COVID-19 Active Response and Expenditure Support Program," 2020. Available at https://www.adb.org/sites/default/files/project-documents/54177/54177-001rrp-en.pdf

[4] Asian Development Bank, "Proposed Countercyclical Support Facility Loans, Republic of Indonesia: COVID-19 Active Response and Expenditure Support Program," 2020. Available at https://www.adb.org/sites/default/files/project-documents/54139/54139-001rrp-en.pdf

[5] Asian Development Bank, "Proposed Loan Republic of the Philippines: Expanded Social Assistance Project," 2020. Available at https://www.adb.org/sites/default/files/projectdocuments/52257/52257-001-rrp-en.pdf 
International Journal of Social Science and Economic Research

ISSN: 2455-8834

Volume:06, Issue:04 "April 2021"

[6] Ashwini Deshpande, "The Covid-19 Pandemic and Lockdown: First Effects on Gender Gaps inEmployment and Domestic Work in India," Ashoka University, 2020. Available at https://ideas.repec.org/p/ash/wpaper/30.html.

[7] Biju Varkkey, Rupa Korde and Devansh Parikh. "Indian Labour Market and Position of Women: Gender Pay Gap in the Indian Formal Sector," 2017. Available at https://bit.ly/3mz9Don

[8] Centre for Monitoring Indian Economy, "Economic Outlook Database." Available at bit.ly/33AbjXF

[9] Dalberg, “Addressing Women's Time Poverty in India," 2020. Available at https://dalberg.com/our-ideas/addressing-womens-time-poverty-in-india/

[10] Esther Duflo, “Women's Empowerment and Economic Development," Massachusetts Instituteof Technology and CEPR, 2012. Available at https://bit.ly/33FldXQ

[11] Giorgia Barboni, Erica Field, Rohini Pande, Natalia Rigol, Simone Schaner and Charity TroyerMoore. "A Tough Call: Understanding barriers to and impacts of women's mobile phone adoption in India," Harvard Kennedy School, 2018. Available at https://bit.ly/36wBIao

[12] GSMA,"The Mobile Gender Gap Report 2020," 2020. Available at https://bit.ly/37vM5ub

[13] International Labour Organisation, "India Wage Report," 2018. Available at https://bit.ly/2KQWY28

[14] J. Galbraith, D. Roy Chowdhury and S. Srivastava, "Pay Inequality in the Indian Manufacturing Sector, 1979-98," University of Texas, 2004. Available at: https://utip.lbj.utexas.edu/papers.html

[15] Labour Bureau, "Report on Education, Skill Development and Labour Force," 2015-16. Available at bit.ly/3jzt2nE

[16] Luis A. Andres et al, "Precarious Drop: Reassessing Patterns of Female Labor Force Participation in India," World Bank, 2017. Available at https://bit.ly/2JhKjoL

[17] M. N. Srinivas, "A Note on Sanskritization and Westernization," Association for Asian Studies, 1956. Available at https://www.jstor.org/stable/2941919?seq=1 
International Journal of Social Science and Economic Research

ISSN: 2455-8834

Volume:06, Issue:04 "April 2021"

[18] Ministry of Health and Family Welfare, "National Family Health Survey (NFHS-4) 201516,"Government of India, 2017. Available at http://rchiips.org/nfhs/NFHS4Reports/India.pdf

[19] Ministry of Statistics and Programme Implementation, "Men and Women Statistics," NationalSample Survey Office, Multiple years.

[20] Ministry of Statistics and Programme Implementation, "Periodic Labour Force Survey Reports," Multiple years. Available at https://bit.ly/30CWVMD

[21] Ministry of Statistics and Programme Implementation, "Time Use Survey (JanuaryDecember 2019)," National Statistical Office, 2019. Available at http://mospi.nic.in/sites/default/files/publication_reports/Report_TUS_2019_0.pdf

[22] Panchandan Das, "Wage Inequality in India: Decomposition by Sector, Gender and Activity Status," Economic and Political Weekly, 2012. Available at https://bit.ly/2VubfUE

[23] Puja Vasudeva Dutta, "Accounting for Wage Inequality in India," University of Sussex, 2005. Available at https://bit.ly/33Bjv9V

[24] Sameer Khatiwada and Mia Kim Maceda Veloso, "Net Technology and Emerging occupations: Evidence from Asia,"Asian Development Bank, 2019. Available at https://bit.ly/39vlhx0

[25] Saravan Ravindran and Manisha Shah, "Unintended Consequences of Lockdowns: COVID-19 and the Shadow Pandemic," NBER, 2020. Available at https://www.nber.org/system/files/working_papers/w27562/w27562.pdf

[26] Saundarya Rajesh, Karthik Ekambaram and Anju Rakesh, "Second Careers of Women Professionals: The India Story,” Avtar Group, 2019. Available at https://bit.ly/33AcCWc

[27] Sher Verick, International Labor Organisation. Female Labour Force Participation in Developing Countries, 2012. Available at https://bit.ly/2Vsms83

[28] Shiney Chakraborty, "COVID-19 and Women Informal Sector Workers in India," Economicand Political Weekly, 2020. Available at https://bit.ly/3fZ32B8

[29] Surbhi Ghai, "The anomaly of Women's Work and Education in India," ICRIER, 2018. Available at bit.ly/30UGiw7 
International Journal of Social Science and Economic Research

ISSN: 2455-8834

Volume:06, Issue:04 "April 2021"

[30] Surjit S. Bhalla, Ravinder Kaur, "Labour Force Participation of Women in India: Some facts, some queries,” LSE, 2011. Available at https://bit.ly/33xEb2K

[31] UNDP, “COVID-19 Global Gender Response Tracker,” 2020. Available at https://data.undp.org/gendertracker/ 